\title{
A NEW HYBRID FUZZY CYBERNETIC ANALYTIC NETWORK PROCESS MODEL TO IDENTIFY SHARED RISKS IN PPP PROJECTS
}

\section{Alireza VALIPOUR a , Nordin YAHAYA ${ }^{a}$, Norhazilan MD NOOR ${ }^{a}$, Abbas MARDANI ${ }^{b}$, Jurgita ANTUCHEVIČIENE் c,*}

${ }^{a}$ Department of Structure and Materials, Construction Technology and Management Centre (CTMC), Universiti Teknologi Malaysia, Skudai, Johor, Malaysia

${ }^{b}$ Department of Management, Universiti Teknologi Malaysia (UTM), Skudai, Johor, Malaysia

${ }^{c}$ Department of Construction Technology and Management, Vilnius Gediminas Technical University, Sauletekio al. 11, LT-10223 Vilnius, Lithuania

Received 14 April 2015; accepted 20 November 2015

\begin{abstract}
A proper risk management strategy is essential in property management. For controlling and reducing risks on Public-Private Partnership (PPP) project, risk allocation is a major component of PPP risk management. Identifying appropriate shared risks and optimal risk allocation in a structured way is a complex process. The aim of this study is to develop a quantitative approach for equitable risk allocation with attention to identifying dependencies between risk allocation criteria and barriers. The paper presents an approach in the form of a hybrid Fuzzy method and Cybernetic Analytic Network Process (CANP) model for identifying shared risks. The approach involves the use of Fuzzy sets to convert linguistic principles and experiential expert knowledge into systematic quantitative analysis and the CANP to solve the problem of dependency and feedback between criteria and barriers as well as selection of shared risks. A case study is presented to demonstrate the use of the model in selecting shared risks. The study involves development of 10 criteria and 8 barriers. Finally, of 40 significant risks, 14 risks are successfully allocated between the public and private sector in Iranian PPP projects.
\end{abstract}

KEYWORDS: Property management; Risk allocation; Shared risks; Fuzzy Cybernetic Analytic Network Process (FCANP); Public-Private Partnership (PPP)

SUPPLEMENTARY MATERIAL associated with this article can be found, in the online version, at http://dx.doi.org/10.3846/1648715X.2016.1210547

\section{INTRODUCTION}

Risk allocation is a vital factor to achieve success in property management, including implementation of Public-Private Partnership projects (Chan et al. 2010; Liu, Wilkinson 2014; Yun et al. 2015). Public-Private Partnership (PPP) is "a contractual contract between a private and public sector" whereby an economic resources and also the skills of each sector are shared to fulfil the public requirement for public products or services (Ke et al. 2010) and suitable allocation of risks, resources, and rewards (Canadian Council for PPP 2013). Although PPP has many benefits (Carbonara et al. 2014), this system has some drawbacks related to complexities in planning, arrangement in relation to documentation, the dynamic nature,

\footnotetext{
* Corresponding author. E-mail: jurgita.antucheviciene@vgtu.lt
}

capital budget and taxation, control, monitoring, performance, politics and policies (Grimsey, Lewis 2002). Most of the risks arise from these types of complexities in PPP projects (Heravi, Hajihosseini 2011). Usually PPP projects are failing to achieve budget, deadlines, and quality. There were 327 unsuccessful PPP projects from 1990 to 2012 in the world. It is observed that Latin America and East Asia and Pacific countries have the highest failure rate in terms of number of projects cancelled, i.e. 135 and 86 projects respectively. The number of PPP projects that have failed in SubSaharan Africa, South Asian, Europe and Central Asia, and Middle East and North Africa were 50, 13, 36 and 7 respectively (World Bank 2015). Examples include National Sewerage project in Malaysia, the Betuwe Railway, the parker Shop Den 
Bosch in Netherlands, Railway project in Sydney (Ng, Loosemore 2007), Kerman Power Plant and Chalus-Tehran Toll Road in Iran (Heravi, Hajihosseini 2011), the Sydney cross city Tunnel, the 9th plant in Zhang Zhou city and the Sydney link Airport.

It is essential for private and public sectors to apply efficient PPP risk allocation approaches to experience a more effective process of agreement arbitration and to reduce the occurrence of dispute during the concession period (Alireza et al. 2013). Improper risk allocation has negative impacts on the success of a PPP project in terms of time, cost, and quality (Doloi 2012; Ke et al. 2012, 2013). A recent survey by the Construction Industry Institute (CII) concludes that inappropriate allocation of risk results at least a $3 \%$ contingency in bids (CII 2006). The study by Zaghloul and Hartman (2003) reports that using disclaimer clauses to allocate risks adds a premium of between $8 \%$ and $20 \%$ to construction project bids, depending on whether business conditions were favourable, fair or high. Accordingly, unbalanced risk allocation may cause increased costs for both parties in contract (Jin, Zhang 2011). Improper allocation of risks is common in the construction industry that leads to adversarial interaction contract, disputes and claims (Kumaraswamy 1997). In addition, the cost of inappropriate allocation of risk could be seen in the reaction from contractors, for example adding a high contingency (premium) to the bid cost or the delivery of poor quality work (Khazaeni et al. 2012b; Lam et al. 2007). Accordingly, it is very important for the public and private sector to choose an ideal pattern of risk allocation in order to make strategic decisions.

Proper risk allocation is a complex and flexible process, which often causes conflict between the partners in PPP projects. Equitable risk allocation depends on many factors and barriers, such as the ability to manage risk and the attitude of stakeholders towards shared responsibility (Iqbal et al. 2015) and risk (Lam et al. 2007; Zhang et al. 2002; Tserng et al. 2014). The process of risk allocation should be recognized based on the abilities of both parties in PPP projects. There are several barriers associated with risk allocation in the construction industry, such as cooperation, negotiation, teamwork, collaboration, trust and communication (Valipour et al. 2014). For instance, a lack of trust can be a major barrier to the collaborative connection between project partners (Akintoye, Main 2007). Therefore, it is necessary to broadly consider the criteria and barriers of risk allocation to achieve appropriate risk allocation (Valipour et al. 2014; Xu et al. 2010).

Based on the previous studies summarized above, a scarcity of research was observed regarding the risk allocation model for PPP projects in Iran. The lack of published literature in this respect reinforces the significance of this study. This research is thus essential and timely to further enrich the knowledge base on PPP in the construction industry. There is a lack of risk allocation models based on risk allocation barriers and criteria in previous research. Lack of evaluation on independency and feedback between risk allocation criteria and barriers on project objectives is one of the reasons for weak risk allocation model of PPP projects. It is vital for the private and public sectors to completely understand the various risks related to PPPs through the whole life cycle of infrastructure projects, the significance of risks and the best way to allocate them to ensure longterm achievement of partnerships. The identification, classification, evaluation and investigation of problems of this particular current practice of allocation of risk and also the identification, classification, evaluation of criteria and barriers to optimal risk allocation in the PPP project can represent an authentic contribution to the body of knowledge and to the PPP projects.

The current research develops an innovative decision model based on dependency and feedback between risk allocation criteria and barriers to systematically identify shared risks and quantitative risk allocation method for PPP projects. The study utilizes CANP (Cybernetic Analytic Network Process) to overcome the problems of feedback and dependency among the criteria and barriers, and Fuzzy set theory to quantify and augment the linguistic expert knowledge. The results of the study can help project owners or property managers as well as contractors and subcontractors to achieve better risk management, cost and time savings, and improve the overall quality of PPP projects.

The findings of the current study provide insight into ways to improve the performance of property development and maintenance PPP projects, especially in developing countries because of a lack of experience and published literature related to risk allocation of PPP projects in these localities. In these countries, the advantages of privatization programs are not well understood, and such projects typically rely more on the government than the private sector for financing. Therefore the findings derived from this study could also serve as a useful reference for desirable risk allocation for similar PPP projects. 


\section{RELATED RESEARCH}

Previous studies have implied that there are two approaches for risk allocation, including qualitative and quantitative approaches (Khazaeni et al. 2012a). Several researches have suggested criteria and principles for distribution of an equitable risk (Abrahamson 1973; Jin, Doloi 2008; Khazaeni et al. 2012a; Lam et al. 2007; Thomas et al. 2003; Valipour et al. 2014; Xu et al. 2010). All these risk allocation criteria and principles relied on the qualitative judgment of the experts. Notably, the most of the previous researches indicate that the questionnaire survey method is suitable for development of a risk allocation framework. For instance, Bing et al. (2005) developed a risk allocation model based on questionnaire survey with 53 suitable responses for projects in the UK. In addition, Roumboutsos and Anagnostopoulos (2008) compared allocation of risk in the PPP projects in Greece and the UK, using a questionnaire survey. El-Sayegh (2008) conducted a similar survey to uncover the appropriate risk allocation between the contracting parties in the UAE construction industry. Loosemore and McCarthy (2008) studied risk allocation in construction and supply chains using a questionnaire survey. Another example is Jin and Doloi (2008), who applied an industry-wide survey for examining a framework for the allocation of risk in PPP projects. Hwang et al. (2013) studied perception of risk allocation in PPP project in Singapore and 11 risks were preferred to be shared by public and private sector. Carbonara et al. (2015) defined the most significant risks and identified the effective allocation strategies.

Very few research studies have focused on developing a quantitative model for the allocation of risk. Medda (2007) has developed a risk allocation model using a game theory approach. Meanwhile, Lam et al. (2007) used fuzzy set theory in a quantitative model for risk allocation based on qualitative expert knowledge and linguistic principles. Jin and Zhang (2011) has put a great effort to develop a model of risk allocation using artificial neural network. Xu et al. (2010, 2012) developed a fuzzy synthetic evaluation method to obtain a proper risk allocation. For evaluating risks in infrastructure projects AHP method was used (Al-Azemi et al. 2014) or fuzzy logic was applied (Yazdani-Chamzini 2014). A fuzzy AHP approach was provided to balance the risk allocation (Khazaeni et al. 2012a). Rudzianskaite-Kvaraciejiene et al. (2015) applied Random Forest technique for modelling effectiveness of PPP projects.
In addition, the case study is another method to find an equitable risk allocation scheme between partners in the PPP projects. A number of researches used a case study of risk allocation, including Abednego and Ogunlana (2006) that studied an equitable risk allocation in a PPP toll way project in Indonesia. Wang and Chou (2003) investigated risk allocation and the response to risk on a highway project in Taiwan. $\mathrm{Ng}$ and Loosemore (2007) studied risk allocation on a railway project in Sydney. Xu et al. $(2011,2014)$ summarized experience from PPP projects in China.

Review of previous studies on risk allocation indicated that there was a lack of quantitative and comprehensive models for selecting the optimal allocation of risk. During the recent years, some researchers tried to propose appropriate risk allocation patterns for the construction projects, but most of the related studies have the following limitations and problems. There is a lack of models to identify shared risks based on risk allocation barriers and criteria. Lack of evaluation on independency and feedback between risk allocation criteria and barriers on project objectives is one of the reasons for weak risk allocation model of PPP projects. Accordingly, it was found that risk allocation is often influenced by the agents themselves (Thomas et al. 2003), attitudes towards risk, as well as management capabilities (Jin, Zhang 2011). Lack of attention to the relationship between criteria and barriers can lead to inappropriate risk allocation (Valipour et al. 2014). The influence of criteria and barriers can lead to a significant variation in the decision outcomes regarding risk allocation based on attitude, manageability, and acceptability of the risk between partners. In order to minimize time and cost as well as to maximize the quality, shared risks should be distributed to the appropriate party. Accordingly, the current study provides a quantitative method to identify shared risk through a Fuzzy CANP approach by utilizing the process to overcome the problems of feedback and interdependency among the risk allocation criteria and barriers. Due to the uncertainty and vagueness of judgments of the decision makers, the crisp pairwise comparison in the traditional ANP appears to be insufficient and too imprecise to accurately capture the judgments associated with decision makers. Therefore fuzzy theory was used to overcome the problem of uncertainty and vagueness of judgments. Notably, the use of a fuzzy set concept in risk allocation permits qualitative risk allocation explanations to be modelled mathematically. 


\section{RESEARCH METHODOLOGY}

The flow of the research methodology for the study is schematically illustrated in Figure 1. The following sections describe the methods that were applied in each stage through the case study.

The research consists of four main stages. The first stage is focused on the identification of relative risks in PPP projects. It identifies risk allocation criteria and barriers. This stage has been accomplished through conducting a comprehensive literature review, such as journals, articles, books, internet sources, newspapers and holding informal discussions with experts and researchers.
The second stage is focused on the sample size and selecting of experts. The random sampling technique is used in this stage.

The third stage includes two parts. The first part is focused on the identification of significant risks. It is conducted through questionnaire and risk analysis matrix. The second part is focused to identify significant risk allocation criteria and barriers. The criteria and barriers are evaluated through ANP approach. This part includes creating a network structure and a pilot survey by ex-

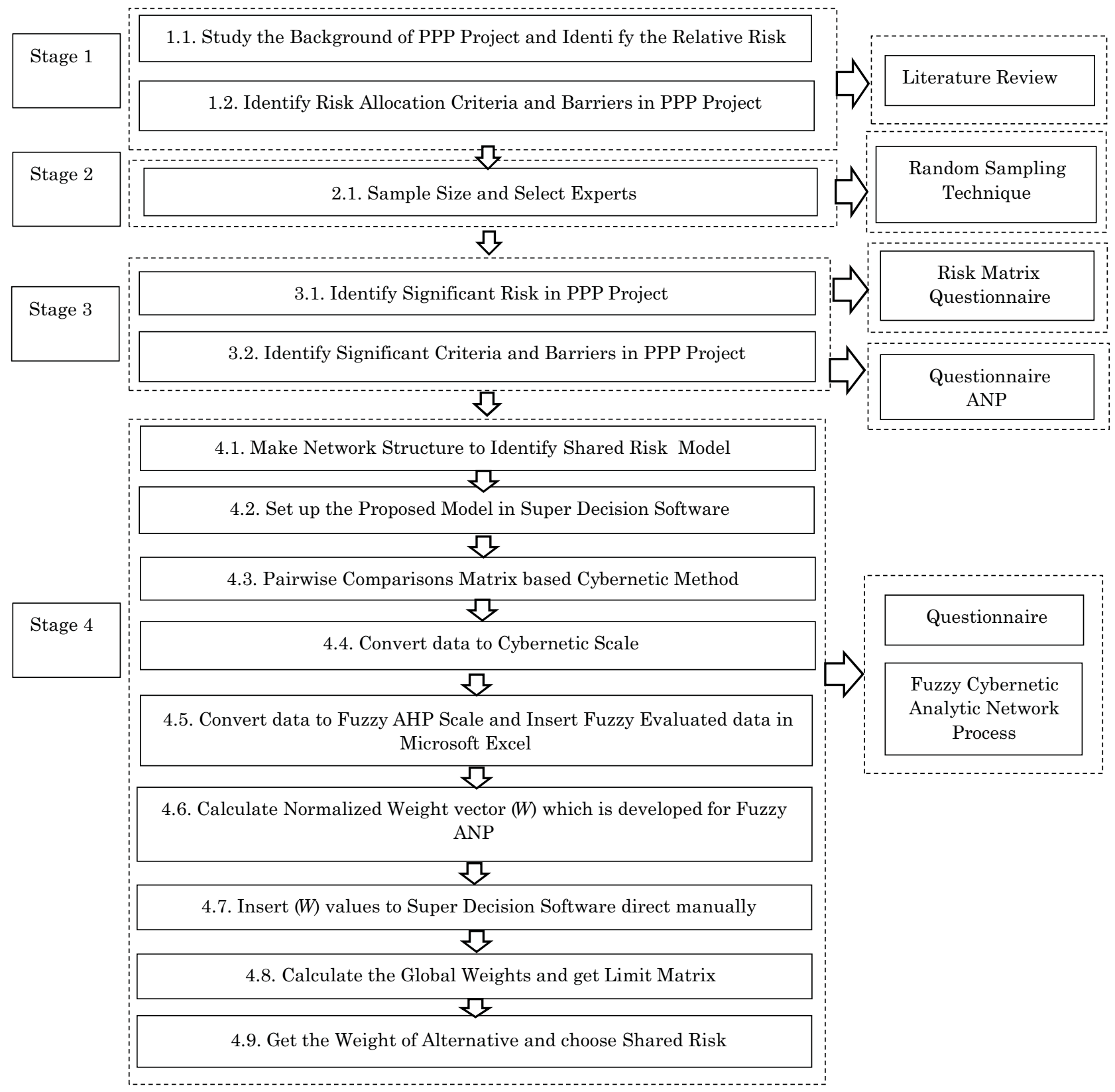

Fig. 1. Research methodology: stages and techniques 
perts, questionnaire design, questionnaire distribution and questionnaire analysis by ANP method.

The fourth stage is focused to identify shared risks. A multi criteria decision making model is developed based on FCANP risk allocation model. This part includes making network structure based on significant risks and risk allocation criteria and barriers, questionnaire distribution and questionnaire analysis by FCANP method.

Forasmuch as risks and risk allocation on each PPP project is unique, therefore the stakeholders of different projects can used the proposed model only by replacing the information and data on their projects such as important risks, criteria and barriers in the purpose model. It does not only reduce time and costs during selection phase, but also diminishes the conflict and hidden costs in the implementation stage. The proposed model can be applied into complex and multi-party contract strategy rather than to risk allocation between sectors in a contract arrangement.

\subsection{Case study to identify shared risk allocation in Iranian PPP projects}

To demonstrate the proposed methodology, an applicable example is analysed in the current part of the research. Ability to identify shared risks between the Public and Private sectors is illustrated. In Iran, a developing country with a broad geographic area, power plant, water and sewerage network and road network expansion is very important. The Iranian government attracts private investment in construction of infrastructure through PPP contracts. As in many other developing countries, insufficient experience, the shortage of related studies, and the complexity of PPP contracts have presented serious problems for PPP projects.

\subsection{Questionnaire}

The primary data for this study was obtained through a comprehensive literature review. The questionnaire survey was conducted as a secondary resource to collect data for this study. The first part of the questionnaire requested basic information on the respondents.

The second part required the respondents to express their views about risk based on PPP projects, compiled from previous similar studies. Regarding frequency and impact, the 5-point Likert scale is represented as $1=$ Very Low; $2=$ Low; $3=$ On Average; 4 = High; and 5 = Very High.
The third part was designed to evaluate the criteria and risk allocation barriers for PPP projects in Iran. Finally, the research questionnaire was designed to evaluate how to allocate each risk factor to various sectors. A pairwise comparison and 1-9 Fuzzy AHP scale (Chang 1996) was used as a measurement scale for this part.

\subsection{Sample size}

A sample is usually a group of individuals included as participants who supply the information, details, or ideas for a study. Findings from a study sample could be generalized to the general population (Kothari 2004). In this study, the sample involved public and private sectors in PPP projects in Iran. The random sampling technique is utilized when there is an equal geographic distribution among samples. The sample size that represented the population for the questionnaire was determined using the following formulas (Al-Tmeemy et al. 2012):

$$
S S=\frac{z^{2} p(1-p)}{c^{2}},
$$

where: $S S$ is the calculated sample size; $z$ is $\mathrm{z}$ value for the confidence level (e.g. 1.96 for $95 \%$ confidence level); $p$ is percentage picking a choice, expressed as decimal ( 0.5 used for sample size needed); $c$ is confidence interval.

The calculated sample size (SS) was then corrected for finite population using Equation 2:

$$
\text { Corrected } S S=\frac{S S}{1+\left(\frac{S S-1}{p o p}\right)},
$$

where: $p o p$ is population.

Later, the corrected sample size (Corrected SS) was adjusted for the response rate using Equation 3:

Corrected $S S$ for $r r=r r$. Corrected $S S$,

where: $r r$ is response rate. A $65 \%$ response rate is a typical rate used for an online survey.

\subsection{Mean index}

It was necessary to identify the important risks in Iranian PPP projects. According to qualitative methods and the research questionnaire, each participant was required to reveal the level of frequency of the risk event and the degree of the risk impact. In this regard, mean analysis was used to determine the mean of frequency and risk impact. Mean can be calculated by using SPSS according to the formula below (Abdul-Aziz, Jahn Kassim 2011):

$$
\text { Mean Index }=\frac{\sum_{i=1}^{n} a_{i} x_{i}}{n},
$$


where: $a_{i}$ is constant, expressing the weight to each response ( 1 to 5 ); $x_{i}$ is frequency of the response, $i=1,2, \ldots, n ; n$ is a total number of responses.

The mean results of frequency and risk impact were then used to calculate the risk score.

\subsection{Risk analysis matrix}

The Risk Analysis Matrix is a quantitative method which uses a subjective evaluation table of low, medium, and high indications to demonstrate the amount of every type of risk mentioned (Alireza et al. 2013). Risk scores are determined by multiplying mean of frequency and mean of risk impact:

$$
\text { Risk Score }=F_{r} \cdot I_{r} \text {, }
$$

where: $F_{r}$ is the mean of frequency of risk occurrence; $I_{r}$ is the risk impact mean.

Respondents are presented with a scale to rate the provided statements based on how frequently the risk occurs as well as its impact by using 5 -point Likert Scale. This rating system is applied to the frequency levels of PPP project risk occurrence and the impact level of PPP risk. Table 1 shows the rating of the risk analysis matrix. Consequently, a list of the major risks in Iranian PPPs is the core objective of this step.

Table 1. Risk analysis matrix

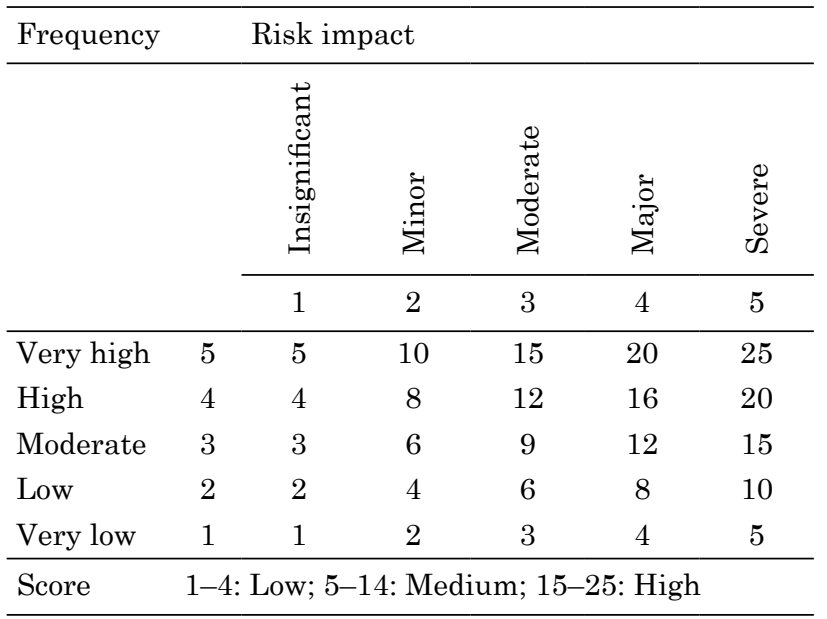

\subsection{Fuzzy cybernetic analytic network process (FCANP)}

A cybernetic approach provides the application of analytic network process (ANP) in order to avoid the bottleneck problem in data collection through questionnaire surveys. To set up a more accurate ANP model, it is required to have more number of responses. While Chen (2010) provided a data transforming method which is useful even if number of responses is less. The various combinations of 1 to 9 scales were created, and these types of combinations are usually categorized under a further scale of 1 to 9 that assigns values to combinations in the super-matrix synthesis during pair-wise comparison in the ANP method. This data-transforming method is presented in Table 2.

ANP was developed to solve complex decision making problems by Saaty (Saaty, Vargas 2006). ANP is a powerful method to determine complex inter-relationships and to incorporate feedback among decision levels and attributes. Accordingly, ANP is used to determine the relationship between clusters of elements that influence each other and are influenced by elements in other clusters. In fact, ANP enables researchers to analyse influences separately according to many factors, and then combines them into a single result (Ayağ, Özdemir 2007; Chan et al. 2008). This approach is the most accurate method to model complex decision problems, able to evaluate tangible and intangible features (Rabbani et al. 2014). In ANP, pairwise comparison judgments can be used to determine the relevant importance and dominance among elements and components. ANP uses Saaty's 9-point scale to match the AHP (Wu et al. 2008).

However, the decision maker may misinterpret opinions and may be uncertain in dedicating the evaluation in a different number. Uncertainty may exist as a result of incomplete information, inaccurate information and partial ignorance (Cheng,

Table 2. Cybernetic scales

\begin{tabular}{lll}
\hline Scale & Linguistic scale terms & Paired comparison of indicators/criteria \\
\hline 1 & Equal & $1: 1$ \\
2 & Equally to moderately dominant & $2: 1,3: 2,4: 3,5: 4,6: 5,7: 6,8: 7,9: 8$ \\
3 & Moderately dominant & $3: 1,4: 2,5: 3,6: 4,7: 5,8: 6,9: 7$ \\
4 & Moderately to strongly dominant & $4: 1,5: 2,6: 3,7: 4,8: 5,9: 6$ \\
5 & Strongly dominant & $5: 1,6: 2,7: 3,8: 4,9: 5$ \\
6 & Strongly to very strongly dominant & $6: 1,7: 2,8: 3,9: 4$ \\
7 & Very strongly dominant & $7: 1,8: 2,9: 3$ \\
8 & Very strongly to extremely dominant & $8: 1,9: 2$ \\
9 & Extremely dominant & $9: 1$ \\
\hline
\end{tabular}


Tang 2009). Hence, AHP and ANP methods can fail to adequately handle the associated ambiguities and inherent uncertainty in mapping the decision-maker's concept to exact numbers. In order to ensure the accuracy of the representation of human judgments, fuzzy set theory has been compounded in ANP methods. Zadeh (1976) introduced the fuzzy set theory to deal with problems regarding the explanation of activities, and perception and judgments that are intellectually ambiguous and imprecise.

The current study uses the extent analysis method as introduced by Chang (1996). The method is employed to calculate priority weights from fuzzy comparison matrices. The steps of extent analysis method are provided as follows: Let $X=$ $\left\{x_{1}, x_{2}, \ldots, x_{n}\right\}$ be an object set and $G=\left\{g_{1}, g_{2}\right.$, $\left.\ldots, g_{n}\right\}$ be a goal set. According to the method of Chang's extent analysis, each object is taken and an extent analysis for each goal $\left(g_{i}\right)$ is performed. Thus, extent analysis values for each object can be obtained as follows:

$$
M_{g_{i}}^{1}, M_{g_{i}}^{2}, \ldots, M_{g_{i}}^{m}, i=1,2, \ldots, n,
$$

where: $M_{g_{i}}^{j}$ are triangular fuzzy numbers demoted by $\left(l_{j}, m_{j}, u_{j}\right), j=1,2, \ldots ., m$.

Step 1: The value of fuzzy synthetic extent $\left(S_{i}\right)$ with respect to the $i^{\text {th }}$ object is defined as:

$$
S_{i}=\sum_{j=1}^{m} M_{g_{i}}^{j} \otimes\left[\sum_{i=1}^{n} \sum_{j=1}^{m} M_{g_{i}}^{j}\right] .
$$

To obtain $\sum_{j=1}^{m} M_{g_{i}}^{j}$, the fuzzy addition operation of extent analysis values for the matrix is performed as:

$$
\sum_{j=1}^{m} M_{g_{i}}^{j}=\left(\sum_{j=1}^{m} l_{j}, \sum_{j=1}^{m} m_{j}, \sum_{j=1}^{m} u_{j}\right) .
$$

To obtain $\left[\sum_{i=1}^{n} \sum_{j=1}^{m} M_{g_{i}}^{j}\right]^{-1}$, the fuzzy additional operation of $M_{g_{i}}^{j}(j=1,2, \ldots, m)$ values is performed as:

$$
\sum_{i=1}^{n} \sum_{j=1}^{m} M_{g_{i}}^{j}=\left(\sum_{i=1}^{n} l_{i}, \sum_{i=1}^{n} m_{i}, \sum_{i=1}^{n} u_{i}\right),
$$

and then the inverse of the vector is computed:

$$
\left[\sum_{i=1}^{n} \sum_{j=1}^{m} M_{g_{i}}^{j}\right]^{-1}=\left(\frac{1}{\sum_{i=1}^{n} u_{i}}, \frac{1}{\sum_{i=1}^{n} m_{i}}, \frac{1}{\sum_{i=1}^{n} l_{i}}\right) .
$$

Step 2: The degree of possibility of $M_{2}=\left(l_{2}\right.$, $\left.m_{2}, u_{2}\right) \geq M_{1}=\left(l_{1}, m_{1}, u_{1}\right)$ is defined as:

$$
V\left(M_{2} \geq M_{1}\right)=\sup _{y \geq x}\left[\min \left(\mu_{M_{1}}(x), \mu_{M_{2}}(y)\right)\right]
$$

and can be equivalently expressed as follows:

$$
\begin{aligned}
& V\left(M_{2} \geq M_{1}\right)=h g t\left(M_{1} \cap M_{2}\right)=\mu_{M_{2}}(d)= \\
& \begin{cases}1 & \text { if } \mathrm{m}_{2} \geq m_{1} \\
0 & \text { if } \mathrm{l}_{1} \geq u_{2}, \\
\frac{l_{1}-u_{2}}{\left(m_{2}-u_{2}\right)-\left(m_{1}-l_{1}\right)} & \text { otherwise }\end{cases}
\end{aligned}
$$

where: $d$ is the ordinate of the highest intersection point $D$ between $\mu_{M 1}$ and $\mu_{M 2}$. To compare $M_{1}$ and $M_{2}$, we need both the values of $V\left(M_{1} \geq M_{2}\right)$ and $V\left(M_{2} \geq M_{1}\right)$.

Step 3: The degree possibility for a convex fuzzy number to be greater than $k$ convex fuzzy numbers, $M_{i}, i=1,2, \ldots, k$ can be defined by:

$V\left(M \geq M_{1}, M_{2}, \ldots, M_{k}\right)=V\left[\left(M \geq M_{1}\right)\right.$ and $\left(M \geq M_{2}\right)$ and $, \ldots,\left(M \geq M_{k}\right)=\min V\left(M \geq M_{i}\right)$, $i=1,2, \ldots, k$.

Assume that $d^{\prime}\left(A_{i}\right)=\min V\left(S_{i} \geq S_{k}\right)$ for $k=1$, $2, \ldots, n ; k \neq i$. Then the weight vector is given by:

$W^{\prime}=\left(d^{\prime}\left(A_{1}\right), d^{\prime}\left(A_{2}\right), \ldots, d^{\prime}\left(A_{n}\right)\right)^{\mathrm{T}}, i=1,2, \ldots, n$.

Step 4: The normalized weight vectors are:

$$
\begin{aligned}
& d\left(A_{i}\right)=\frac{d^{\prime}\left(A_{i}\right)}{\sum_{i=1}^{n} d^{\prime}\left(A_{i}\right)}, \\
& W=\left(d\left(A_{1}\right), d\left(A_{2}\right), \ldots, d\left(A_{n}\right)\right)^{T},
\end{aligned}
$$

where: $W$ is a non-fuzzy number.

\section{APPLICATION OF FCANP FOR THE CASE STUDY}

\subsection{Sample size}

The sample size that represents population for the survey is calculated based on the Equation 1. In the study, the targeted size of population is 250 public and private experts involved in PPP project in Iran. For the purpose of getting the maximum sample size, the value of $p$ was taken as 0.5 . The confidence level $z$ was taken to be $95 \%$, and the maximum standard error allowed $c$ in this study was taken as $10 \%$. Applying the above formulae, the sample size was calculated using a Microsoft Excel work sheet, and the results are listed in Table 3.

An expert team was then organized to support the implementation of the questionnaire survey. For this study, 64 experts were selected from Iran, 
Table 3. Sample size calculation

\begin{tabular}{lll}
\hline Percentage $(p)$ & 0.5 & \\
\hline Confidence interval $(c)$ & 0.1 & 0.975 \\
Confidence level and $z$ value & $95 \%$ & 1.96 \\
Response rate $(r r)$ & $92 \%$ & $\cdots--$ \\
Population & 250 & $\cdots---$ \\
\hline Total & & 64 \\
\hline
\end{tabular}

including a deputy director, an owner, a quantity manager, a contracts manager, contractors, a designer, a senior manager, and a cost control administrator from various organizations including Iranian Public Private Partnership Unit and Construction Industry. The respondents had to meet two criteria before being invited to participate in the survey: first, they needed to have extensive work experience within the construction industry of Iran; and second, they needed to be involved in the management of PPP projects or have gained in-depth knowledge of the PPP model through research. The background information of the respondents: $58.4 \%$ of the respondents came from the private sector, $39.8 \%$ came from the public sector, and the rest mainly comprised of selected researchers and academicians. Nearly $51 \%$ of the respondents had $11-5$ years of industrial experience, $11 \%$ - above 16 years of industrial experience.

\subsection{Identification of significant risks}

Several risks were identified in the first stage. This was achieved primarily through literature review of significant previous research (Bing et al. 2005; Ke et al. 2010; Heravi, Hajihosseini 2011; Ghorbani et al. 2014; Karim 2011). As a result, 92 PPP project risk factors were successfully identified. Data was collected through questionnaires that were distributed through email and in person amongst a sample of public and private sectors in Iranian PPP projects. Based on the survey outcomes, a mean score was computed for each PPP project risk factor based on the related Risk Frequency and Risk Impact (Eq. 4-5). These risks were then ranked according to a risk score and risk analysis matrix (scales 1-25). Figure 2 shows the Frequency-Impact matrix, while Table 4 shows the 40 significant risk factors for the PPP projects in Iran. These risks were categorized into eight groups.

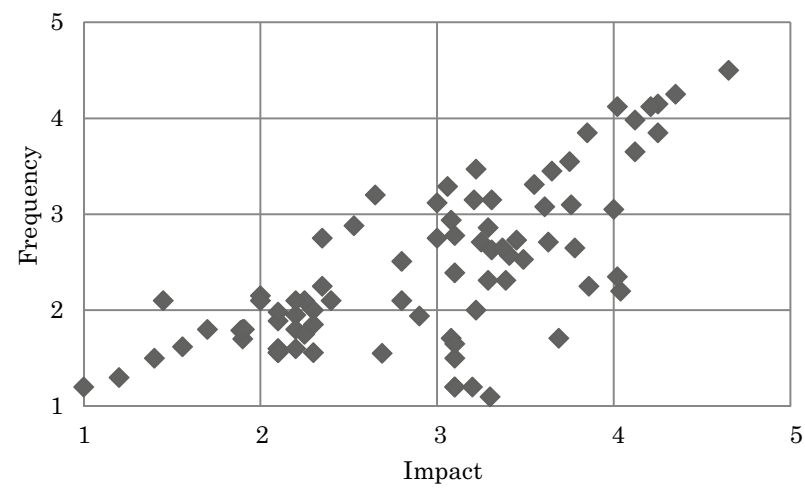

Fig. 2. Frequency-Impact matrix

Table 4. Significant risks in Iranian PPP project

\begin{tabular}{|c|c|c|}
\hline Risk groups & Types of risks & Risk score \\
\hline \multirow[t]{8}{*}{$\mathrm{R}_{1}:$ Financial } & $\mathrm{r}_{11}$ : Change in value of granted lands due to development & 15.84 \\
\hline & $\mathrm{r}_{12}:$ Inflation risk & 18.06 \\
\hline & $\mathrm{r}_{13}:$ Change in value of granted lands due to inflation & 17.64 \\
\hline & $\mathrm{r}_{14}:$ Financial problems due to environmental protection & 15.99 \\
\hline & $\mathrm{r}_{15}:$ Need for land appraisal & 14.06 \\
\hline & $\mathrm{r}_{16}:$ Limited capital & 17.22 \\
\hline & $\mathrm{r}_{17}:$ Foreign exchange rate fluctuations & 20.70 \\
\hline & $\mathrm{r}_{18}:$ Interest rates & 16.91 \\
\hline \multirow[t]{9}{*}{$\mathrm{R}_{2}:$ Legal } & $\mathrm{r}_{21}:$ Improper design & 15.28 \\
\hline & $\mathrm{r}_{22}$ : Delay in resolving contractual dispute & 14.35 \\
\hline & $\mathrm{r}_{23}$ : Inadequate study and insufficient data & 17.22 \\
\hline & $\mathrm{r}_{24}:$ Need for environmental approval & 15.52 \\
\hline & $\mathrm{r}_{25}:$ Ownership assets & 14.43 \\
\hline & $\mathrm{r}_{26}:$ Lack of standard model for PPP agreements & 16.56 \\
\hline & $\mathrm{r}_{27}:$ Need for land acquisitions & 16.80 \\
\hline & $\mathrm{r}_{28}:$ Changes in law & 17.20 \\
\hline & $\mathrm{r}_{29}$ : Delay in resolving litigation or arbitration dispute & $\begin{array}{l}17.80 \\
\text { (Contin }\end{array}$ \\
\hline
\end{tabular}




\begin{tabular}{|c|c|c|}
\hline Risk groups & Types of risks & Risk score \\
\hline \multicolumn{3}{|l|}{ (Continued) } \\
\hline \multirow[t]{5}{*}{$\mathrm{R}_{3}:$ Political } & $\mathrm{r}_{31}$ : Arbitrary termination of concession by government & 14.30 \\
\hline & $\mathrm{r}_{32}:$ Influential economic events & 16.40 \\
\hline & $\mathrm{r}_{33}:$ Poor public decision-making process & 14.76 \\
\hline & $\mathrm{r}_{34}:$ Unstable government & 16.30 \\
\hline & $\mathrm{r}_{35}:$ Sanction & 16.40 \\
\hline \multirow[t]{4}{*}{$\mathrm{R}_{4}:$ Market } & $\mathrm{r}_{41}:$ Demand below anticipation & 12.47 \\
\hline & $\mathrm{r}_{42}:$ Arbitrary definition of tariff of services by government & 7.59 \\
\hline & $\mathrm{r}_{43}:$ Insufficient income & 11.16 \\
\hline & $\mathrm{r}_{44}:$ Competition & 9.28 \\
\hline \multirow[t]{4}{*}{$\mathrm{R}_{5}:$ Operation } & $\mathrm{r}_{51}:$ Operator default & 8.80 \\
\hline & $\mathrm{r}_{52}:$ Operating revenues below expectation & 10.34 \\
\hline & $\mathrm{r}_{53}:$ Operation cost overrun & 7.59 \\
\hline & $\mathrm{r}_{54}:$ Low operating productivity & 11.70 \\
\hline \multirow{2}{*}{$\begin{array}{l}\mathrm{R}_{6}: \text { Organization and } \\
\text { coordination }\end{array}$} & $\mathrm{r}_{61}:$ Lack of coordination \& commitment & 8.64 \\
\hline & $\mathrm{r}_{62}:$ Organization risk & 11.78 \\
\hline \multirow[t]{3}{*}{$\mathrm{R}_{7}:$ Natural } & $\mathrm{r}_{71}:$ Weather & 9.90 \\
\hline & $\mathrm{r}_{72}:$ Force majeure & 16.80 \\
\hline & $\mathrm{r}_{73}:$ Environment & 13.20 \\
\hline \multirow[t]{5}{*}{$\mathrm{R}_{8}$ : Construction } & $\mathrm{r}_{81}:$ Third party delays & 13.30 \\
\hline & $\mathrm{r}_{82}:$ Construction completion delay & 11.88 \\
\hline & $\mathrm{r}_{83}:$ Construction cost overrun & 11.20 \\
\hline & $\mathrm{r}_{84}:$ Availability of material / labour & 11.40 \\
\hline & $\mathrm{r}_{85}:$ Site availability & 12.40 \\
\hline
\end{tabular}

\subsection{Identification of significant risk allocation criteria and barriers}

A detailed review of books and relevant journal papers, interviews with PPP experts and questionnaire survey were also adopted to collect data to identify significant risk allocation criteria and barriers. After conducting a comprehensive literature review of PPP projects and risk allocation criteria and barriers, a total of 20 criteria and 17 barriers for optimal risk allocation of PPP projects were identified. Table 5 and Table 6 show the significant criteria and barriers.

Table 5. Significant risk allocation criteria in Iranian PPP project

\begin{tabular}{l}
\hline Criteria \\
\hline $\mathrm{C}_{1}:$ Identification of risk \\
$\mathrm{C}_{2}$ : Foreseen of risk \\
$\mathrm{C}_{3}$ : Evaluation of risk \\
$\mathrm{C}_{4}:$ Bear the risk at the lowest price \\
$\mathrm{C}_{5}:$ Capability of control risk \\
$\mathrm{C}_{6}$ : Control the chance of risk \\
$\mathrm{C}_{7}:$ Minimize the loss if risk occurs \\
$\mathrm{C}_{8}:$ Expertise of control risk \\
$\mathrm{C}_{9}$ : Assume the direct \\
$\mathrm{C}_{10}$ : Risk attitude \\
\hline
\end{tabular}

Table 6. Significant risk allocation barriers in Iranian PPP project

Barriers

$\mathrm{D}_{1}$ : Aversion to risk by project participants

$\mathrm{D}_{2}$ : Imbalance and abuse of power

$\mathrm{D}_{3}$ : Lack of understanding benefits of optimal allocation

$\mathrm{D}_{4}$ : Lack of trust among project participants

$\mathrm{D}_{5}$ : Lack of efficient risk allocation mechanism

$\mathrm{D}_{6}$ : Complexity of contracts

$\mathrm{D}_{7}$ : Staging involvement of project participants

$\mathrm{D}_{8}$ : Different sets of information about project risk

The risk allocation criteria and barriers which the Delphi expert team identified as the most important were extracted, as reported by Valipour et al. (2014), and applied in the proposed model. To summarize the opinions of experts from questionnaire survey and ANP, a total of 10 risk allocation criteria and 11 risk allocation barriers for Iranian PPP projects were identified.

\subsection{Application of FCANP to identify shared risks}

The risk factor "Interest rates" $\left(\mathrm{r}_{18}\right)$ was chosen to illustrate how to use the model to quantitatively determine the shared risks of PPP project. After 
the identification and evaluation of important risks, risk allocation criteria and barriers, a network structure was constructed by experts to create mutual influence between each risk factor, criteria, barriers and alternatives based on risk allocation.

Inserting data in Super Decision Software is the next step after determining dependency between each element. The first step in building the ANP model is to decide on the logical groupings of the nodes and clusters that structure the problem. The clusters that build the model included cluster of goals and cluster of criteria and barriers. Figure 3 shows the ANP network structure including clusters and alternatives. The purpose of this section is to make ANP network structure to identify shared risks. Therefore, all the comparison questions are asked from the perception of risk allocation for each risk based on criteria and barriers.

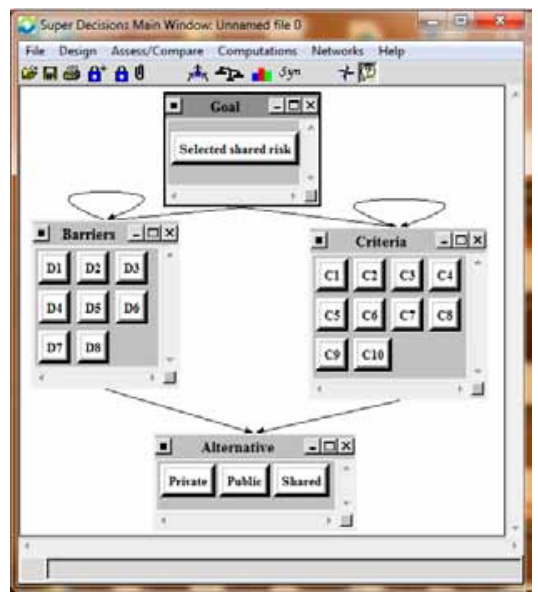

Fig. 3. ANP network structure

Upon the formation of the ANP shared risks allocation structure and consensus on its elements, the next step was to conduct pairwise comparison matrices in Microsoft Excel to solve FANP matrix. Two set pairwise comparison questionnaire was prepared based on cybernetic approach. The following question was given to the respondents to compare allocation of each risk factor based on optimal risk barriers and criteria in the first and second questionnaire, respectively. All data obtained from this step was converted to cybernetic scale.
The interdependence matrix of each risk factor was determined relative to the criteria and barriers on fuzzy scales. The scale used was based on Chang's fuzzy method (Chang 1996) and it is presented in Table 7. A triangular fuzzy number was inserted in the related Microsoft Excel sheet according to the result received from this linguistic scale. All the average comparisons obtained from the expert answers were solved using Microsoft Excel. Since FCANP identify shared risk approaches by taking into consideration several criteria, and most of these are qualitative, it may be difficult to quantitatively asses these criteria. Thus, the judgment to determine relative importance or dominance of an element or component to that of other element or component in pair-wise comparison was expressed as a linguistic variable. Consistency ratio $C R$ was used to check consistency according to the pairwise comparison. If the consistency value of $C R$ is less than 0.10 , it evidences that the pairwise comparison matrix contains satisfactory consistency.

Data was processed using Microsoft Excel sheet to determine inter-dependency for any subnet, the inter-dependence matrix of each criteria and barriers with regard to the other criteria and barriers with fuzzy scale. Alternatives were also considered based on all the elements and sub-elements. The respondents presented their particular comparisons. The related weights for the alternatives were determined considering risk allocation based on each criteria and barrier using Microsoft Excel sheet. These computations are repetitive for every criterion in the criteria and barriers cluster and its subnets until all alternatives are concluded. For instance, fuzzy pairwise comparison matrix of Expertise of control risk $\left(\mathrm{C}_{8}\right)$ criteria factors and fuzzy pairwise comparison matrix of Imbalance and abuse of power $\left(\mathrm{E}_{2}\right)$ barrier factors using the question "perception of risk allocation" are provided in Table 8 and Table 9. The significance of both the impact of criteria on the alternatives and also the influence from the criteria on themselves must be regarded in the ANP computation procedure.

Table 7. Fuzzy scale

\begin{tabular}{llll}
\hline Linguistic scale for difficulty & Linguistic scale for importance & Triangular fuzzy scale & $\begin{array}{l}\text { Triangular fuzzy } \\
\text { reciprocal scale }\end{array}$ \\
\hline Just equal & Just equal & $(1,1,1)$ & $(1,1,1)$ \\
Equally difficult & Equally important & $(1 / 2,1,3 / 2)$ & $(2 / 3,1,2)$ \\
Weakly more difficult & Weakly more important & $(1,3 / 2,2)$ & $(1 / 2,2 / 3,1)$ \\
Strongly more difficult & Strongly more important & $(3 / 2,2,5 / 2)$ & $(2 / 5,1 / 2,2 / 3)$ \\
Very strongly more difficult & Very strongly more important & $(2,5 / 2,3)$ & $(1 / 3,2 / 5,1 / 2)$ \\
Absolutely more difficult & Absolutely more important & $(5 / 2,3,7 / 2)$ & $(2 / 7,1 / 3,2 / 5)$
\end{tabular}


Table 8. Comparison matrix for $\mathrm{C}_{8}$

\begin{tabular}{lllll}
\hline $\mathrm{C}_{18}$ & Private & Public & Shared & $W$ \\
\hline Private & $(1,1,1)$ & $(1,2,3)$ & $(1 / 3,1 / 2,1)$ & 0.468 \\
Public & $(1 / 3,1 / 2,1)$ & $(1,1,1)$ & $(1 / 4,1 / 3,1 / 2)$ & 0.066 \\
Shared & $(1,2,3)$ & $(2,3,4)$ & $(1,1,1)$ & 0.468 \\
& & & & $C R=0.052$ \\
\hline
\end{tabular}

Table 9. Comparison matrix for $\mathrm{E}_{2}$

\begin{tabular}{lllll}
\hline $\mathrm{E}_{14}$ & Private & Public & Shared & $W$ \\
\hline Private & $(1,1,1)$ & $(1 / 3,1 / 2,1)$ & $(1,2,3)$ & 0.359 \\
Public & $(1,2,3)$ & $(1,1,1)$ & $(2,3,4)$ & 0.572 \\
Shared & $(1 / 3,1 / 2,1)$ & $(1 / 4,1 / 3,1 / 2)$ & $(1,1,1)$ & 0.068 \\
& & & & $C R=0.008$ \\
\hline
\end{tabular}

Solving FANP matrices supplies us with the normalized weight vectors $(W)$ using Chang's extent analysis method. Here $W$ is a non-fuzzy number. Normalized weight vectors of elements and sub-elements are calculated utilizing Microsoft Excel sheet. This particular sheet is made to create normalized weight vectors which will be inserted into Super Decisions software. Normalized weight vectors for barrier factors using the question $\left(\mathrm{E}_{2}\right)$ are provided below as a numerical example:

$s_{c_{11}}=(2.33,3.5,5) \otimes(0.0645,0.0882,0.1263)=$ $(0.1505,0.3088,0.6315)$,

$s_{c_{12}}=(4,6,8) \otimes(0.0789,0.1034,0.132)=(0.2580$, $0.5294,1.010)$

$s_{c_{14}}=(1.58,1.83,2.5) \otimes(0.0789,0.1034,0.132)=$ (0.1021, 0.16176, 0.3157).

The degrees of possibility were calculated as follows:

$V\left(s_{c_{11}} \geq s_{c_{12}}\right)=0.6287, V\left(s_{c_{11}} \geq s_{c_{14}}\right)=$

$1, V\left(s_{c_{12}} \geq s_{c_{11}}\right)=1, V\left(s_{c_{12}} \geq s_{c_{14}}\right)=$

$1, V\left(s_{c_{14}} \geq s_{c_{11}}\right)=0.529, V\left(s_{c_{14}} \geq s_{c_{12}}\right)=0.119$.

For each pairwise comparison, the minimum of the degrees of possibility was determined as follows:

$V\left(s_{c_{11}} \geq s_{c_{12}}, s_{c_{14}}\right)=\min \{0.6287,1\}=0.6287$,

$V\left(s_{c_{12}} \geq s_{c_{11}}, s_{c_{14}}\right)=\min \{1,1\}=1, V\left(s_{c_{14}} \geq s_{c_{11}}\right.$,

$\left.s_{c_{12}}\right)=\min \{0.529,0.119\}=0.119$.
These values yielded the following weight vector:

$W^{\prime}=(0.629,1,0.119)$.

Via normalization, the local weights of the criteria were determined as follows:

$W=(0.359,0.572,0.068)$.

Next, $W$ values can be entered manually to Super Decisions software. Super Decisions limits the weighted super matrix by increasing it to a completely large power $k$ (where $k$ is definitely a random large number) until this converges into a steady super matrix (also referred to as a limiting or constant-state super matrix). The weighted super matrix can be elevated to large powers until all elements in every row converge in the software. A presented part of limited super matrix shows the significance of weight elements (Table 10).

Then we can choose the best part of risk allocation for Interest rate $\left(\mathrm{r}_{18}\right)$ using alternative scores. Raw values are summed up and each row in the raw column can be divided through the sum in order to get normal values. To obtain ideal values, each value in the raw values column is separated by the greatest value of the column as seen in Figure 4 . The results are $0.218,0.638$ and 0.143 for alternatives (private, shared and public), respectively.

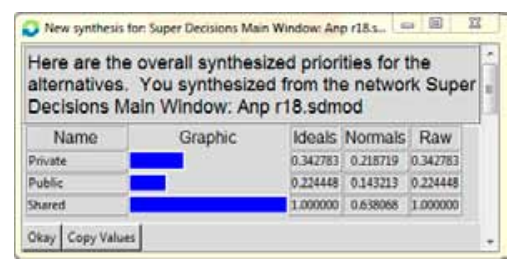

Fig. 4. Final results to allocated interest rate risk

\section{RESULTS AND DISCUSSION}

\subsection{Final perception of risk allocation}

The minimum response rate of $55 \%$ is adopted based on previous studies in US (Kangari 1995), Kuwait (N. A. Kartam, S. A. Kartam 2001), UAE (El-Sayegh 2008), Indonesia (Andi 2006) to the

Table 10. Limited super matrix for Interest rates $\left(\mathrm{r}_{18}\right)$

\begin{tabular}{|c|c|c|c|c|c|c|c|c|}
\hline \multicolumn{2}{|c|}{ Cluster node labels } & \multicolumn{3}{|c|}{ Alternative } & \multicolumn{4}{|c|}{$\mathrm{B}_{1}$ : Risk management competency } \\
\hline \multirow[b]{2}{*}{ Alternative } & & Private & Public & Shared & $\mathrm{C}_{11}$ & $\mathrm{C}_{12}$ & $\mathrm{C}_{13}$ & $\mathrm{C}_{14}$ \\
\hline & Private & 0.000 & 0.000 & 0.000 & 0.046 & 0.046 & 0.046 & 0.046 \\
\hline \multirow{6}{*}{$\mathrm{C}_{1}$} & Public & 0.000 & 0.000 & 0.000 & 0.032 & 0.032 & 0.032 & 0.032 \\
\hline & Shared & 0.000 & 0.000 & 0.000 & 0.174 & 0.174 & 0.174 & 0.170 \\
\hline & $\mathrm{C}_{11}$ & 0.000 & 0.000 & 0.000 & 0.035 & 0.035 & 0.035 & 0.035 \\
\hline & $\mathrm{C}_{12}$ & 0.000 & 0.000 & 0.000 & 0.007 & 0.007 & 0.007 & 0.007 \\
\hline & $\mathrm{C}_{13}$ & 0.000 & 0.000 & 0.000 & 0.016 & 0.016 & 0.016 & 0.016 \\
\hline & $\mathrm{C}_{14}$ & 0.000 & 0.000 & 0.000 & 0.081 & 0.081 & 0.081 & 0.081 \\
\hline
\end{tabular}


allocated risk for each partner. As a result of the study, 14 shared risks in Iranian PPP projects were identified. These risks include Inflation risk $\left(\mathrm{r}_{12}\right)$, Financial problems due to environmental protection $\left(\mathrm{r}_{14}\right)$, Foreign exchange rate fluctuations $\left(\mathrm{r}_{17}\right)$, Interest rates $\left(\mathrm{r}_{18}\right)$, Improper design $\left(\mathrm{r}_{21}\right)$, Need for environmental approval $\left(\mathrm{r}_{24}\right)$, Delay in resolving litigation or arbitration dispute $\left(\mathrm{r}_{29}\right)$, Influential economic events $\left(\mathrm{r}_{32}\right)$, Lack of coordination \& commitment $\left(\mathrm{r}_{61}\right)$, weather $\left(\mathrm{r}_{71}\right)$, Force majeure $\left(\mathrm{r}_{72}\right)$, Environment $\left(\mathrm{r}_{73}\right)$, Availability of material/labour $\left(\mathrm{r}_{84}\right)$, Site availability $\left(\mathrm{r}_{85}\right)$.

Table 11 also indicates that 11 risk factors should be allocated to the public sector. These involve Change in value of granted lands due to development residual $\left(\mathrm{r}_{11}\right)$; Delay in resolving contractual dispute

Table 11. Results of risk allocation in Iranian PPP projects

\begin{tabular}{|c|c|c|c|c|c|c|c|c|c|c|c|c|c|}
\hline \multirow[t]{2}{*}{ No } & \multirow[t]{2}{*}{$\begin{array}{l}\text { Risk factor } \\
\text { (code) }\end{array}$} & \multicolumn{4}{|c|}{ Public sector (\%) } & \multicolumn{4}{|c|}{ Private sector (\%) } & \multicolumn{3}{|c|}{$\begin{array}{l}\text { All respondents } \\
(\%)\end{array}$} & \multirow{2}{*}{$\begin{array}{l}\text { Final alloca- } \\
\text { tion }\end{array}$} \\
\hline & & $\operatorname{Pr}$ & $\mathrm{Sh}$ & $\mathrm{Pu}$ & Allocated to & $\operatorname{Pr}$ & $\mathrm{Sh}$ & $\mathrm{Pu}$ & Allocated to & $\operatorname{Pr}$ & $\mathrm{Sh}$ & $\mathrm{Pu}$ & \\
\hline 1 & $\mathrm{r}_{11}$ & 16 & 25 & 59 & public & 15 & 21 & 64 & shared & 14 & 24 & 62 & public \\
\hline 2 & $\mathrm{r}_{12}$ & 7 & 56 & 37 & private & 4 & 65 & 31 & private & 12 & 63 & 25 & shared \\
\hline 3 & $\mathrm{r}_{13}$ & 62 & 15 & 23 & private & 71 & 14 & 15 & private & 69 & 12 & 19 & private \\
\hline 4 & $\mathrm{r}_{14}$ & 20 & 57 & 23 & private & 31 & 55 & 14 & private & 23 & 71 & 6 & shared \\
\hline 5 & $\mathrm{r}_{15}$ & 64 & 24 & 12 & private & 60 & 25 & 15 & private & 62 & 14 & 24 & private \\
\hline 6 & $\mathrm{r}_{16}$ & 58 & 24 & 18 & private & 72 & 12 & 16 & private & 68 & 21 & 11 & private \\
\hline 7 & $\mathrm{r}_{17}$ & 58 & 18 & 24 & private & 24 & 59 & 17 & shared & 23 & 57 & 20 & shared \\
\hline 8 & $\mathrm{r}_{18}$ & 10 & 65 & 25 & shared & 11 & 72 & 17 & shared & 23 & 63 & 14 & shared \\
\hline 9 & $\mathrm{r}_{21}$ & 14 & 72 & 14 & shared & 5 & 80 & 15 & shared & 6 & 82 & 2 & shared \\
\hline 10 & $r_{22}$ & 18 & 24 & 58 & public & 16 & 23 & 61 & public & 31 & 11 & 58 & public \\
\hline 11 & $\mathrm{r}_{23}$ & 58 & 14 & 28 & private & 72 & 13 & 15 & private & 64 & 14 & 22 & private \\
\hline 12 & $\mathrm{r}_{24}$ & 12 & 56 & 32 & shared & 6 & 74 & 10 & shared & 18 & 77 & 5 & shared \\
\hline 13 & $\mathrm{r}_{25}$ & 58 & 16 & 26 & private & 67 & 23 & 10 & private & 64 & 15 & 21 & private \\
\hline 14 & $\mathrm{r}_{26}$ & 22 & 20 & 58 & public & 24 & 15 & 61 & public & 23 & 20 & 57 & public \\
\hline 15 & $\mathrm{r}_{27}$ & 18 & 22 & 60 & public & 7 & 22 & 71 & public & 12 & 20 & 68 & public \\
\hline 16 & $\mathrm{r}_{28}$ & 19 & 23 & 58 & public & 20 & 18 & 62 & public & 24 & 14 & 62 & public \\
\hline 17 & $r_{29}$ & 4 & 22 & 74 & shared & 6 & 82 & 12 & shared & 6 & 89 & 5 & shared \\
\hline 18 & $r_{31}$ & 10 & 30 & 58 & public & 13 & 23 & 64 & public & 10 & 34 & 56 & public \\
\hline 19 & $\mathrm{r}_{32}$ & 21 & 56 & 23 & shared & 21 & 62 & 17 & shared & 29 & 58 & 13 & shared \\
\hline 20 & $r_{33}$ & 12 & 23 & 65 & public & 7 & 20 & 73 & public & 20 & 13 & 67 & public \\
\hline 21 & $\mathrm{r}_{34}$ & 24 & 14 & 60 & public & 23 & 20 & 57 & public & 30 & 12 & 58 & public \\
\hline 22 & $\mathrm{r}_{35}$ & 21 & 17 & 62 & public & 9 & 21 & 70 & public & 9 & 23 & 68 & public \\
\hline 23 & $\mathrm{r}_{41}$ & 76 & 13 & 11 & private & 82 & 6 & 12 & private & 84 & 10 & 6 & private \\
\hline 24 & $\mathrm{r}_{42}$ & 72 & 12 & 16 & private & 60 & 23 & 17 & private & 72 & 12 & 16 & private \\
\hline 25 & $\mathrm{r}_{43}$ & 69 & 15 & 16 & private & 65 & 14 & 21 & private & 64 & 13 & 23 & private \\
\hline 26 & $\mathrm{r}_{44}$ & 38 & 57 & 5 & shared & 59 & 20 & 21 & private & 62 & 17 & 21 & private \\
\hline 27 & $r_{51}$ & 65 & 17 & 18 & private & 77 & 12 & 11 & private & 73 & 22 & 5 & private \\
\hline 28 & $r_{52}$ & 61 & 24 & 15 & private & 67 & 23 & 10 & private & 61 & 22 & 17 & private \\
\hline 29 & $\mathrm{r}_{53}$ & 57 & 31 & 12 & private & 62 & 13 & 25 & private & 58 & 10 & 32 & private \\
\hline 30 & $\mathrm{r}_{54}$ & 58 & 20 & 22 & private & 19 & 67 & 14 & shared & 63 & 15 & 22 & private \\
\hline 31 & $\mathrm{r}_{61}$ & 17 & 62 & 21 & shared & 69 & 18 & 13 & private & 13 & 64 & 23 & shared \\
\hline 32 & $\mathrm{r}_{62}$ & 12 & 13 & 75 & public & 20 & 8 & 72 & public & 9 & 15 & 76 & public \\
\hline 33 & $r_{71}$ & 4 & 71 & 25 & shared & 3 & 85 & 12 & shared & 5 & 77 & 18 & shared \\
\hline 34 & $\mathrm{r}_{72}$ & 21 & 56 & 23 & shared & 16 & 63 & 21 & shared & 22 & 64 & 13 & shared \\
\hline 35 & $\mathrm{r}_{73}$ & 5 & 82 & 13 & shared & 3 & 88 & 9 & shared & 5 & 81 & 14 & shared \\
\hline 36 & $\mathrm{r}_{81}$ & 87 & 10 & 3 & private & 69 & 21 & 10 & private & 82 & 12 & 6 & private \\
\hline 37 & $r_{82}$ & 72 & 16 & 12 & private & 81 & 10 & 9 & private & 76 & 13 & 11 & private \\
\hline 38 & $\mathrm{r}_{83}$ & 64 & 23 & 13 & private & 57 & 24 & 19 & private & 60 & 18 & 22 & private \\
\hline 39 & $r_{84}$ & 21 & 63 & 16 & shared & 57 & 24 & 19 & shared & 68 & 14 & 18 & shared \\
\hline 40 & $r_{85}$ & 34 & 58 & 8 & shared & 13 & 64 & 23 & shared & 9 & 59 & 32 & shared \\
\hline
\end{tabular}

$\mathrm{R}=$ risk, $\mathrm{Pr}=$ private, $\mathrm{Sh}=$ shared, $\mathrm{Pu}=$ public 
$\left(\mathrm{r}_{22}\right)$; Lack of standard model for PPP agreements $\left(\mathrm{r}_{26}\right)$; Need for land acquisitions $\left(\mathrm{r}_{27}\right)$; Changes in law $\left(\mathrm{r}_{28}\right)$; Arbitrary termination of concession by government $\left(\mathrm{r}_{31}\right)$; Poor public decision-making process $\left(\mathrm{r}_{33}\right)$; Sanction $\left(\mathrm{r}_{35}\right)$; Unstable government $\left(\mathrm{r}_{34}\right)$; Organization risk $\left(\mathrm{r}_{62}\right)$ and Ownership assets $\left(\mathrm{r}_{25}\right)$.

Finally, the result demonstrates that 15 risk factors are favored to be allocated to private sector. These risks include: Change in value of granted lands due to inflation $\left(\mathrm{r}_{13}\right)$; Need for land appraisal $\left(\mathrm{r}_{15}\right)$; Limited capital $\left(\mathrm{r}_{16}\right)$; Inadequate study and insufficient data $\left(\mathrm{r}_{23}\right)$; Demand below anticipation $\left(\mathrm{r}_{41}\right)$; Arbitrary definition of tariff of services by government $\left(\mathrm{r}_{42}\right)$; Insufficient income $\left(\mathrm{r}_{43}\right)$; Competition $\left(\mathrm{r}_{44}\right)$; Operator default $\left(\mathrm{r}_{51}\right)$; Operating revenues below expectation $\left(r_{52}\right)$; Operation cost overrun $\left(\mathrm{r}_{53}\right)$; Low operating productivity $\left(\mathrm{r}_{54}\right)$; Third party delays $\left(\mathrm{r}_{81}\right)$; Construction completion delay $\left(\mathrm{r}_{82}\right)$ and Construction cost overrun $\left(\mathrm{r}_{83}\right)$.

\subsection{Comparison of public and private sector perception on allocation of PPP project risks}

The second hypothesis of this study was:

$\mathrm{H}_{\mathrm{o}}$ : There is no significant difference in risk allocation between private and public sector in Iran.

$\mathrm{H}_{\mathrm{a}}$ : There is a significant difference in risk allocation between private and public sector in Iran.

In the current section the analysis aims to compare perception of public and private sector on the allocation of PPP project risk. Mann-Whitney test was used to compare publics and privates perception. This test used to find whether there is any significant difference in perception on risks allocation between them. Only three out of 40 risks have Asymptotic Significant value $<$ a value (0.05), including Foreign exchange rate fluctuations $\left(\mathrm{r}_{17}\right)$, Competition $\left(\mathrm{r}_{44}\right)$ and Lack of coordination \& commitment $\left(\mathrm{r}_{61}\right)$. All these risks were rejecting the $\mathrm{H}_{0}$ and have significant difference between publics and privates perception. Table 12 shows that the highest total mean was Limited capital $\left(\mathrm{r}_{16}\right)$ with score of 0.992 . This means that respondents perceived this risk as the most impact risk in PPP project. This is because a private sector is the main financial support for the whole project. If unfortunately this risk happens, the private sector will be unable to make the payment to continue the construction and this will cause project delay or the project will be closed down and abandoned midway due to lack of funds. Among these three risks, the most significant differences in perception of public and private sector were Lack of coordination \& commitment $\left(\mathrm{r}_{61}\right)$ with the smallest value of Asymptotic Significance of 0.016. The table on asymptotic significance for risk allocation is presented in Supplementary Appendix 1 (Table A1).

\subsection{Validation of the risk allocation model}

Eight interviews by experts were launched for validating the model. The model was offered to the experts to make certain that they realized the background of this research, the procedure for how this particular model was created, and the possible application of the model throughout the faceto-face interviews. A question-and-answer session was organized to provide them a chance to raise questions if they had any about the contents of the presentation. Finally, the experts were asked to fill out a validation form with five multiple-choice questions using a 5-point Likert scale, where 1 denoted "poor" and 5 denoted "excellent". As the result, the average scores of all of the five criteria were above 3.50. Accordingly, it was confirmed by the experts in the validation exercise (Yeung et al. 2007) that the Model is considered to be comprehensive, clear, objective, practical and reliable. The results of the validation are presented in Table 12 .

Balance regarding allocation of risk is a crucial project success factor. Based on Figure 5, it can be seen that the findings of Bing et al. (2005), Ke et al. (2010) and Roumboutsos and Anagnostopoulos (2008) have a tendency to protect more risk by private sector, whilst results of this research are likely a balance of shared shift risks between public and private sector. Outcomes of the methodology offered in this research are closer to findings of Hwang et al. (2013), even though some of the risks have been allocated differently.

Table 12. Results of validation exercise for FANP risk allocation model

\begin{tabular}{|c|c|c|c|c|c|c|c|c|c|}
\hline \multirow{2}{*}{$\begin{array}{l}\text { Validation criteria } \\
\text { 1. Degree of Comprehensiveness of } \\
\text { Risks included in the Model }\end{array}$} & \multicolumn{8}{|c|}{ Scores rated by experts } & \multirow{2}{*}{$\begin{array}{l}\text { Average scores } \\
4.250\end{array}$} \\
\hline & 4 & 5 & 3 & 4 & 5 & 4 & 5 & 4 & \\
\hline 2. Degree of Objectivity of the Model & 5 & 4 & 5 & 4 & 3 & 4 & 5 & 5 & 4.375 \\
\hline 3. Degree of Clarity of the Model & 4 & 4 & 5 & 3 & 4 & 4 & 5 & 3 & 4.000 \\
\hline 4. Overall Reliability of the Model & 4 & 5 & 3 & 4 & 4 & 4 & 4 & 5 & 4.125 \\
\hline 5. Degree of Practicality of the Model & 3 & 3 & 4 & 5 & 5 & 4 & 4 & 4 & 4.000 \\
\hline
\end{tabular}




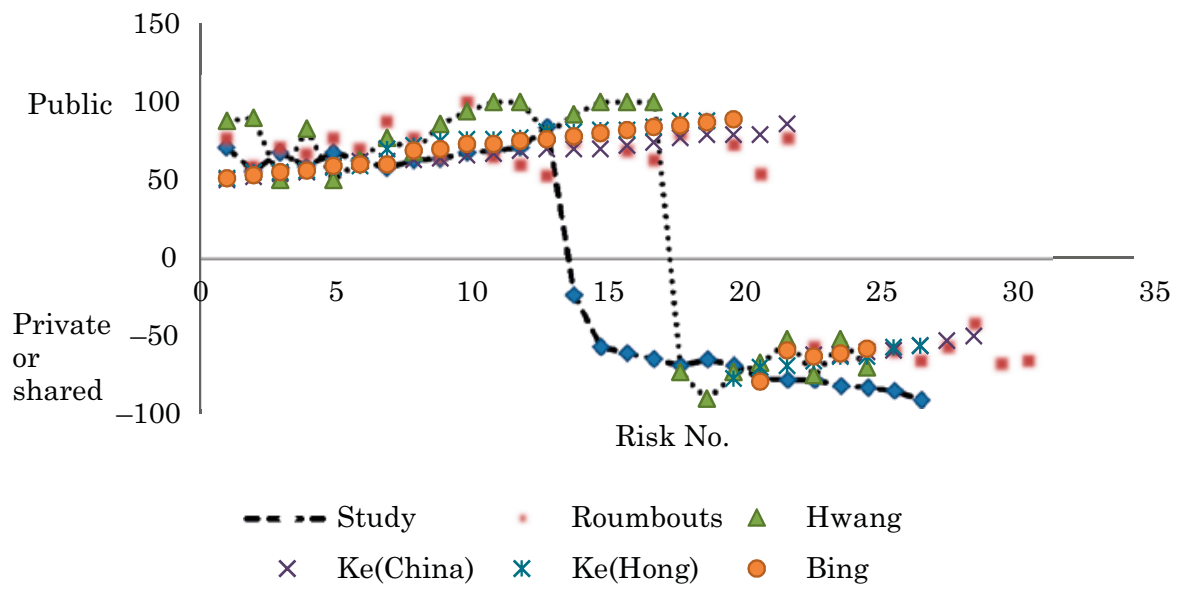

Fig. 5. Results of application of proposed model in comparison with previous studies

\subsection{Sensitivity analysis}

The main purpose of sensitivity analysis is to discover the stability of the best alternatives after some possible changes in variables (Agha et al. 2013). Sensitivity analysis is essential to determine the validity of solutions that might assist in reducing uncertainties in parameters and ideas (Triantaphyllou et al. 1998).

In the current research sensitivity analysis is conducted to determine the changes in the particular ranking of alternatives and the changes in particular weights from the main factors pro-

Table 13. Various values and sensitivity analysis based on $\mathrm{r}_{18}$ criterion

\begin{tabular}{lllll}
\hline \multirow{2}{*}{$\begin{array}{l}\text { Input } \\
\text { value }\end{array}$} & \multirow{2}{*}{$\begin{array}{l}\text { Priority } \\
\text { criteria }\end{array}$} & \multicolumn{3}{l}{ Weight of each part } \\
\cline { 3 - 5 } & & Private & Public & Shared \\
\hline- & 0.01 & 0.25 & 0.18 & 0.57 \\
0.05 & 0.06 & 0.25 & 0.18 & 0.57 \\
0.11 & 0.11 & 0.25 & 0.18 & 0.58 \\
0.16 & 0.17 & 0.24 & 0.18 & 0.58 \\
0.21 & 0.22 & 0.24 & 0.18 & 0.58 \\
0.26 & 0.27 & 0.24 & 0.18 & 0.59 \\
0.32 & 0.32 & 0.24 & 0.17 & 0.59 \\
0.37 & 0.37 & 0.23 & 0.17 & 0.59 \\
0.42 & 0.43 & 0.23 & 0.17 & 0.60 \\
0.47 & 0.48 & 0.23 & 0.17 & 0.60 \\
0.50 & 0.53 & 0.22 & 0.14 & 0.63 \\
0.58 & 0.58 & 0.22 & 0.14 & 0.64 \\
0.63 & 0.64 & 0.21 & 0.14 & 0.65 \\
0.68 & 0.69 & 0.21 & 0.14 & 0.65 \\
0.74 & 0.74 & 0.21 & 0.16 & 0.65 \\
0.79 & 0.79 & 0.20 & 0.15 & 0.65 \\
0.84 & 0.84 & 0.20 & 0.14 & 0.66 \\
0.89 & 0.9 & 0.20 & 0.14 & 0.66 \\
0.95 & 0.95 & 0.20 & 0.13 & 0.67 \\
1 & 1 & 0.19 & 0.13 & 0.67 \\
\hline & & & &
\end{tabular}

posed by the respondents employed in this study. To test the stability of the decision, this study performed sensitivity analysis to test the robustness of the decision with respect to changes in the weighting of the criteria and barriers. For sensitivity ranges and to change the weights of main factors, this study adopted the major impacting factor and sub factors vary from 0.05 to 1. Various values were investigated in an order to examine the impact of criteria on the final weights. This section discussed three alternatives and similar outcomes were found for their related sub-elements. Sample sensitivity analysis of the final decision of "interest rate" risk is shown in Table 13. The alternative rating does not change if the relative significance is increased from 0.5 and decreased from 0.5. This shows that ranking of alternatives does not change if managerial preferences and the ideas of the experts increase or decrease. Therefore, at this particular level,

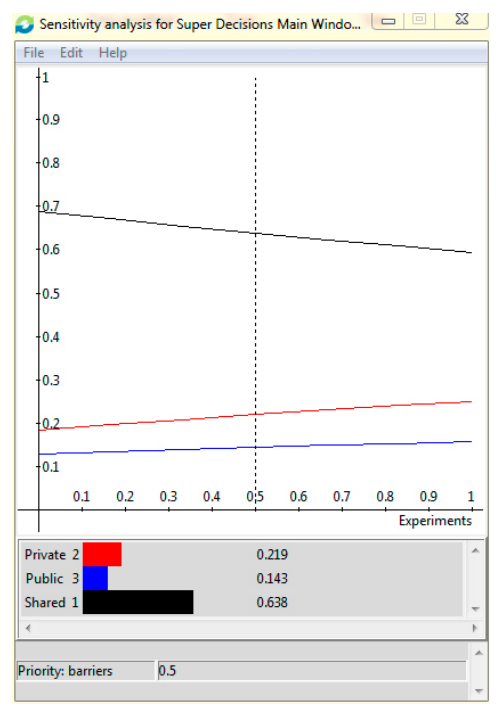

Fig. 6. Sensitivity analysis of the model based on $\mathrm{r}_{18}$ criterion 
the solution is extremely robust with little change in ultimate selection. Stakeholders in PPP projects can be confident that sharing between partners for each risk is a better choice. The sample of sensitivity analysis of the final decision based on interest rate risk is shown in Figure 6.

\section{CONCLUSIONS}

Decision making for identification shared risks in property management has always involved complexity and uncertainty especially when the decision maker deals with large number of decision barriers, criteria and alternatives. The private sector averse to accept the risks while the public sector tends to shift all of risks to them. Inappropriate risk allocation has led to adversarial relationships between contracting participants and has consequently increased project cost and time and decreased project quality. Thus, it is very important for the public and private sector to choose an ideal pattern of risk allocation in order to make strategic decisions.

In this study a quantitative approach to enhance equitable risk allocation in PPP projects has been developed and also the significant risks, risk allocation barriers and criteria in Iranian PPP project were identified.

A Fuzzy Cybernetic Analytic Network Process model (FCANP) has been used for equitable risk allocation which converts linguistic principles and experiential expert knowledge into systematic quantitative-based analysis by using fuzzy logic and solves the problem of independency and feedback between criteria and barriers using ANP method.

Based on the interview findings and results of the questionnaire survey, the 40 important risks inherent to Iranian PPP projects were identified. In addition, 17 criteria and 15 barriers to risk allocation were identified through literature review, of which 10 criteria and 8 barriers were proposed as significant in Iran. A network structure risk allocation model was constructed by experts. Finally, a total of 40 significant risks, 11 risks were allocated to the public sector, 15 risks were allocated to the private sector and 14 risks shared between public and private sector.

This paper has explained the nature of the Iranian PPP project and how the issue of risk allocation is a central one to participants in PPP project. It has developed a theory to define efficient risk allocation and constructed a framework to help policy makers ensure that the risk allocation achieved in their projects is efficient. This paper also applied that framework to a number of case studies and surveyed the industry to determine the validity of the theory and related framework. However, there is much which is still uncertain. The contribution to knowledge made by this research is only the beginning of a rich field of study relating to project risk allocation. In particular, this paper has raised a number of issues, which remain unresolved and require further attention. Private firms, which seek to provide infrastructure services, act on the basis of obtaining profits for their shareholders. They are uncomfortable with risking their capital on projects where many of the factors that could influence the project's outcome are outside of their control.

This study contributes to the literature in some areas. The first is the identification of key risk dimensions and the likely levels, associated with each risk attribute, inferential to PPP projects. Through the process of investigation, the acquired knowledge about key stakeholder perceptions of risk and the associated mitigating factors has opened the possibility of investigating the risk allocation in PPPs from the behavioral perspective. The second contribution is the diagnosis of the PPP procurement method under the lens of contract.

This takes us to the third contribution, the quantification of stakeholders' risk preferences through the calculus of a PPP risk index. Trying to understand barriers to cooperation in reaching equitable risk allocation between the public and private sectors in a principal-agent arrangement, this study not only quantifies risk preferences, but also provides an internally consistent framework, in which the trade-off between risks can be identified, and the extent of barriers that might prevent both parties in identifying areas where they may need to compromise can be gauged.

Results of this study can be applied through the government to enhance risk allocation process, which may encourage the participation of private sectors through better risk allocation. Some key recommendations, stemming from the research, should be considered by any government when they seek to develop PPP projects. These key recommendations are: governments should make any information, which they have and which is relevant to the project, available to tenderers as early in the process as possible; governments should develop a consistent approach to risk allocation in PPP projects. This will increase certainty for private sector bidders and the chances of an optimum outcome being achieved for the community. Governments in 
developing economies or those seeking to develop new industries may be justified in accepting some risks in the short term, which the efficient risk allocation rules would not normally predict. This is because of the prevalence of risk adverse tenderers in new or developing markets. Moreover, no matter how many risks can be allocated easily using the approach set out in this study, there will always be risks which cannot be easily allocated in this way. Governments should be prepared to share these exogenous risks as appropriate, either by pro-rata sharing, capping risks, passing through the costs to consumers, or by simply agreeing to negotiate as appropriate. Government should aim for symmetry in risk allocation.

The results of the proposed model can be in linguistic or numerical form, providing proper risk allocation in PPP projects. The conclusions of the study can be applied through the government to enhance risk allocation process, which may encourage the participation of private sectors through better risk allocation.

\section{ACKNOWLEDGMENT}

The work was financially supported by Universiti Teknologi Malaysia and the Ministry of Science and Technology of Malaysia, MOSTI (Science Fund Grant No. 4S019).

\section{REFERENCES}

Abdul-Aziz, A.-R.; Jahn Kassim, P. 2011. Objectives, success and failure factors of housing public-private partnerships in Malaysia, Habitat International 35: 150-157. http://dx.doi.org/10.1016/j.habitatint.2010.06.005

Abednego, M. P.; Ogunlana, S. O. 2006. Good project governance for proper risk allocation in public-private partnerships in Indonesia, International Journal of Project Management 24: 622-634. http://dx.doi. org/10.1016/j.ijproman.2006.07.010

Abrahamson, M. 1973. Contractual risks in tunnelling: how they should be shared, Tunnels and Tunnelling November: 587-598.

Agha, S. R.; Jarbo, M. H.; Matr, S. J. 2013. A multicriteria multi-stakeholder industrial projects prioritization in Gaza Strip, Arabian Journal for Science and Engineering 38(5): 1217-1227. http://dx.doi. org/10.1007/s13369-012-0346-7

Akintoye, A.; Main, J. 2007. Collaborative relationships in construction: the UK contractors' perception, Engineering, Construction and Architectural Management 14(6): 597-617. http://dx.doi. org/10.1108/09699980710829049

Al-Azemi, K. F.; Bhamra, R.; Salman, A. F. M. 2014. Risk management framework for build, operate and transfer (BOT) projects in Kuwait, Journal of Civil Engineering and Management 20(3): 415-433. http://dx.doi.org/10.3846/13923730.2013.802706

Alireza, V.; Mohammadreza, Y.; Zin, R. M.; Yahaya, N.; Noor, N. M. 2013. An enhanced multi-objective optimization approach for risk allocation in public-private partnership projects: a case study of Malaysia, Canadian Journal of Civil Engineering 41: 164-177. http://dx.doi.org/10.1139/cjce-2013-0342

Al-Tmeemy, S. M. H.; Rahman, H. A.; Harun, Z. 2012. Contractors perception of the use of costs of quality system in Malaysian building construction projects, International Journal of Project Management 30(7): 827-838. http://dx.doi.org/10.1016/j.ijproman.2011.12.001

Andi. 2006. The importance and allocation of risks in Indonesian construction projects, Construction Management and Economics 24(1): 69-80. http://dx.doi. org/10.1080/01446190500310338

Ayağ, Z; Özdemir, R. 2007. An intelligent approach to ERP software selection through fuzzy ANP, International Journal of Production Research 45: 21692194. http://dx.doi.org/10.1080/00207540600724849

Bing, L.; Akintoye, A.; Edwards, P. J.; Hardcastle, C. 2005. The allocation of risk in PPP/PFI construction projects in the UK, International Journal of Project Management 23: 25-35. http://dx.doi.org/10.1016/j. ijproman.2004.04.006

Canadian Council for Public-Private Partnership. 2013. About PPP: Definitions.

Carbonara, N.; Costantino, N.; Gunnigan, L.; Pellegrino, R. 2015. Risk management in motorway PPP projects: empirical-based guidelines, Transport Reviews 35(2): 162-182. http://dx.doi.org/10.1080/01441647.2 015.1012696

Carbonara, N.; Costantino, N.; Pellegrino, R. 2014. Concession period for PPPs: a win-win model for a fair risk sharing, International Journal of Project Management 32(7): 1223-1232. http://dx.doi.org/10.1016/j. ijproman.2014.01.007

Chan, A. P.; Yeung, J. F.; Yu, C. C.; Wang, S. Q.; Ke, Y. 2010. Empirical study of risk assessment and allocation of public-private partnership projects in China, Journal of Management in Engineering 27(3): 136-148. http://dx.doi.org/10.1061/(ASCE)ME.19435479.0000049

Chan, F. T.; Kumar, N.; Tiwari, M.; Lau, H.; Choy, K. 2008. Global supplier selection: a fuzzy-AHP approach, International Journal of Production Research 46: 38253857. http://dx.doi.org/10.1080/00207540600787200

Chang, D.-Y. 1996. Applications of the extent analysis method on fuzzy AHP, European Journal of Operational Research 95: 649-655. http://dx.doi. org/10.1016/0377-2217(95)00300-2

Chen, Z. 2010. A cybernetic model for analytic network process, International Conference on Machine Learning and Cybernetics (ICMLC 2010) 4: 1914-1919.

Cheng, J.-H.; Tang, C.-H. 2009. An application of fuzzy Delphi and fuzzy AHP for multi-criteria evaluation on bicycle industry supply chains, WSEAS Transactions on Systems and Control 4: 21-34. 
CII. 2006. Equitable risk allocation, in CII Research summary 210-1. Construction Industry Institute, Cockrell School of Engineering, University of Texas at Austin.

Doloi, H. 2012. Understanding impacts of time and cost related construction risks on operational performance of PPP projects, International Journal of Strategic Property Management 16(3): 316-337. http://dx.doi. org/10.3846/1648715X.2012.688774

El-Sayegh, S. M. 2008. Risk assessment and allocation in the UAE construction industry, International Journal of Project Management 26: 431-438. http:// dx.doi.org/10.1016/j.ijproman.2007.07.004

Ghorbani, A.; Ravanshadnia, M.; Nobakht, M. B. 2014. A survey of risks in public private partnership highway projects in Iran, in Proceedings of the 2014 International Conference on Construction and Real Estate Management (ICCREM 2014), 27-28 September 2014, Kunming, China, 482-492. http://dx.doi. org/10.1061/9780784413777.058

Grimsey, D.; Lewis, M. K. 2002. Evaluating the risks of public private partnerships for infrastructure projects, International Journal of Project Management 20(2): 107-118. http://dx.doi.org/10.1016/S02637863(00)00040-5

Heravi, G.; Hajihosseini, Z. 2011. Risk allocation in public-private partnership infrastructure projects in developing countries: case study of the Tehran-Chalus Toll road, Journal of Infrastructure Systems 18: 210-217. http://dx.doi.org/10.1061/(ASCE)IS.1943555X.0000090

Hwang, B.-G.; Zhao, X.; Gay, M. J. S. 2013. Public private partnership projects in Singapore: factors, critical risks and preferred risk allocation from the perspective of contractors, International Journal of Project Management 31(3): 424-433. http://dx.doi. org/10.1016/j.ijproman.2012.08.003

Iqbal, S.; Choudhry, R. M.; Holschemacher, K.; Ali, A.; Tamosaitiene, J. 2015. Risk management in construction projects, Technological and Economic Development of Economy 21(1): 65-78. http://dx.doi.org /10.3846/20294913.2014.994582

Jin, X. H.; Doloi, H, 2008. Interpreting risk allocation mechanism in public-private partnership projects: an empirical study in a transaction cost economics perspective, Construction Management and Economics 26: 707-721. http://dx.doi. org/10.1080/01446190801998682

Jin, X.-H.; Zhang, G. 2011. Modelling optimal risk allocation in PPP projects using artificial neural networks, International Journal of Project Management 29(5): 591-603. http://dx.doi.org/10.1016/j.ijproman.2010.07.011

Kangari, R. 1995. Risk management perceptions and trends of US construction, Journal of Construction Engineering and Management 121: 422-429. http://dx.doi.org/10.1061/(ASCE)07339364(1995)121:4(422)

Karim, N. A. A. 2011. Risk allocation in public private partnership (PPP) project: a review on risk factors, International Journal of Sustainable Construction Engineering and Technology 2(2): 62-80.
Kartam, N. A.; Kartam, S. A. 2001. Risk and its management in the Kuwaiti construction industry: a contractors perspective, International Journal of Project Management 19: 325-335. http://dx.doi.org/10.1016/ S0263-7863(00)00014-4

Ke, Y.; Wang, S. Q.; Chan, A. P. 2012. Risk management practice in China s Public-Private Partnership projects, Journal of Civil Engineering and Management 18(5): 675-684. http://dx.doi.org/10.3846/13923730.2 012.723380

Ke, Y.; Wang, S.; Chan, A. P. 2013. Risk misallocation in public-private partnership projects in China, International Public Management Journal 16: 438-460. http://dx.doi.org/10.1080/10967494.2013.825508

Ke, Y.; Wang, S.; Chan, A. P.; Lam, P. T. 2010. Preferred risk allocation in China s public-private partnership (PPP) projects, International Journal of Project Management 28: 482-492. http://dx.doi.org/10.1016/j. ijproman.2009.08.007

Khazaeni, G.; Khanzadi, M.; Afshar, A. 2012a. Fuzzy adaptive decision making model for selection balanced risk allocation, International Journal of Project Management 30: 511-522. http://dx.doi.org/10.1016/j. ijproman.2011.10.003

Khazaeni, G.; Khanzadi, M.; Afshar, A. 2012b. Optimum risk allocation model for construction contracts: fuzzy TOPSIS approach, Canadian Journal of Civil Engineering 39(7): 789-800. http://dx.doi.org/10.1139/ 12012-038

Kothari, C. 2004. Research methodology: methods and techniques. New Age International.

Kumaraswamy, M. 1997. Common categories and causes of construction claims, Construction Law Journal 13: 21-34.

Lam, K. C.; Wang, D.; Lee, P. T.; Tsang, Y. T. 2007. Modelling risk allocation decision in construction contracts, International Journal of Project Management 25: 485-493. http://dx.doi.org/10.1016/j.ijproman.2006.11.005

Liu, T.; Wilkinson, S. 2014. Large-scale public venue development and the application of Public-Private Partnerships (PPPs), International Journal of Project Management 32(1): 88-100.

http://dx.doi.org/10.1016/j.ijproman.2013.01.003

Loosemore, M.; McCarthy, C. 2008. Perceptions of contractual risk allocation in construction supply chains, Journal of Professional Issues in Engineering Education and Practice 134(1): 95-105. http://dx.doi. org/10.1061/(ASCE)1052-3928(2008)134:1(95)

Medda, F. 2007. A game theory approach for the allocation of risks in transport public private partnerships, International Journal of Project Management 25: 213-218. http://dx.doi.org/10.1016/j.ijproman.2006.06.003

Ng, A.; Loosemore, M. 2007. Risk allocation in the private provision of public infrastructure, International Journal of Project Management 25: 66-76. http://dx.doi.org/10.1016/j.ijproman.2006.06.005

Rabbani, A.; Zamani, M.; Yazdani-Chamzini, A.; Zavadskas, E. K. 2014. Proposing a new integrated model based on sustainability balanced scorecard (SBSC) and MCDM approaches by using linguistic variables 
for the performance evaluation of oil producing companies, Expert Systems with Applications 41: 73167327. http://dx.doi.org/10.1016/j.eswa.2014.05.023

Roumboutsos, A.; Anagnostopoulos, K. P. 2008. Publicprivate partnership projects in Greece: risk ranking and preferred risk allocation, Construction Management and Economics 26: 751-763. http://dx.doi. org/10.1080/01446190802140086

Rudzianskaite-Kvaraciejiene, R.; Apanaviciene, R.; Gelzinis, A. 2015. Modelling the effectiveness of PPP road infrastructure projects by applying random forests, Journal of Civil Engineering and Management 21(3): 290-299. http://dx.doi.org/10.3846/13923730.2 014.971129

Saaty, T. L.; Vargas, L. G. 2006. Decision making with the analytic network process: economic, political, social and technological applications with benefits, opportunities, costs and risks. Springer.

The World Bank and the Private Participation in Infrastructure database. [online] 2015. Available at: http://ppi.worldbank.org/explore/Report.aspx

Thomas, A.; Kalidindi, S. N.; Ananthanarayanan, K. 2003. Risk perception analysis of BOT road project participants in India, Construction Management and Economics 21: 393-407. http://dx.doi. org/10.1080/0144619032000064127

Triantaphyllou, E.; Shu, B.; Sanchez, S. N.; Ray, T. 1998. Multi-criteria decision making: an operations research approach, Encyclopedia of Electrical and Electronics Engineering 15: 175-186.

Tserng, H. P.; Ho, S.-P.; Chou, J.-S.; Lin, C. 2014. Proactive measures of governmental debt guarantees to facilitate public-private partnerships project, Journal of Civil Engineering and Management 20(4): 548560. http://dx.doi.org/10.3846/13923730.2013.801883

Valipour, A.; Moharnrnadi, F.; Yahaya, N.; Sarvari, H.; Noor, N. M. 2014. Malaysian public private partnership project case study, Journal of Applied Sciences 14: 2023-2031. http://dx.doi.org/10.3923/ jas.2014.2023.2031

Wang, M.-T.; Chou, H.-Y. 2003. Risk allocation and risk handling of highway projects in Taiwan, Journal of Management in Engineering 19(2): 60-68. http:// dx.doi.org/10.1061/(ASCE)0742-597X(2003)19:2(60)

Wu, C.-R.; Chang, C.-W; Lin, H.-L. 2008. A fuzzy ANPbased approach to evaluate medical organizational performance, International Journal of Information and Management Sciences 19: 53-74.

Xu, Y.; Chan, A. P.; Yeung, J. F. 2010. Developing a fuzzy risk allocation model for PPP projects in China, Journal of Construction Engineering and Manage- ment 136: 894-903. http://dx.doi.org/10.1061/(ASCE) CO.1943-7862.0000189

Xu, Y.; Lu, Y.; Chan, A. P. C.; Skibniewski, M. J.; Yeung, J. F. Y. 2012. A computerized risk evaluation model for public-private partnership (PPP) projects and its application, International Journal of Strategic Property Management 16(3): 277-297. http://dx.doi.org/10.3846/1648715X.2012.686928

Xu, Y.; Yang, Y.; Chan, A. P. C.; Yeung, J. F. Y.; Cheng, H. 2011. Identification and allocation of risks associated with PPP water projects in China, International Journal of Strategic Property Management 15(3): 275-294. http://dx.doi.org/10.3846/16487 15X.2011.617867

Xu, Y.; Yeung, J. F. Y.; Jiang, S. 2014. Determining appropriate government guarantees for concession contract: lessons learned from 10 PPP projects in China, International Journal of Strategic Property Management 18(4): 356-367. http://dx.doi.org/10.3846/16487 15X.2014.971088

Yazdani-Chamzini, A. 2014. Proposing a new methodology based on fuzzy logic for tunnelling risk assessment, Journal of Civil Engineering and Management 20(1): 82-94. http://dx.doi.org/10.3846/13923730.201 3.843583

Yeung, J. F.; Chan, A. P.; Chan, D. W.; Li, L. K. 2007. Development of a partnering performance index (PPI) for construction projects in Hong Kong: a Delphi study, Construction Management and Economics 25(12): 1219-1237.

http://dx.doi.org/10.1080/01446190701598673

Yun, S.; Jung, W.; Han, S. H.; Park, H. 2015. Critical organizational success factors for public private partnership projects - a comparison of solicited and unsolicited proposals, Journal of Civil Engineering and Management 21(2): 131-143. http://dx.doi.org/10.384 6/13923730.2013.802715

Zadeh, L. A. 1976. A fuzzy-algorithmic approach to the definition of complex or imprecise concepts, International Journal of Man-machine Studies 8: 249-291. http://dx.doi.org/10.1016/S0020-7373(76)80001-6

Zaghloul, R.; Hartman, F. 2003. Construction contracts: the cost of mistrust, International Journal of Project Management 21(6): 419-424. http://dx.doi. org/10.1016/S0263-7863(02)00082-0

Zhang, X.; Kumaraswamy, M.; Zheng, W.; Palaneeswaran, E. 2002. Concessionaire selection for build-operate-transfer tunnel projects in Hong Kong, Journal of Construction Engineering and Management 128(2): 155-163. http://dx.doi.org/10.1061/ (ASCE)0733-9364(2002)128:2(155) 